\title{
'n Nuwe horison' - Verkenning ten opsigte van 'n sosiale geskiedenis van die Nederduitse Gereformeerde Sending
}

W Saayman

(Universiteit van Suid-Afrika)

\begin{abstract}
\end{abstract}
\section{A new horizon: reconnaisance in connection with a DRC social mission history, 1934-1961}

The author chooses to write a social mission history of the DRC in order to relate important mission events properly to the developing political economy in South Africa. He chooses to follow the nethodology describe especially by Grundlingh and Hobsbawm. He sees mission history and church history as interchangeable, and views Christian history as an important rubric of general human history. He analyses the period 19341961 in this article, and starts with the DRC mission policy established in 1935. The author points out a close entwinement of mission policy and political culture, in that "the solution of the native question" formed the central pivot in both mission and political policy. He analyses events around the publication of the Tomlinson Report to illustrate the link between mission policy and political culture (segregation/apartheid). There were also voices of protest against these developments, especially from people with missionary involvement. The author is convinced that there are various important areas for further research (which explains why he subtitled his article: "A reconnaisance in terms of social mission history"). Some of these areas are the relationship between mission and financial ability and the DRC's late involvement in urban mission. The author concludes with an ambivalent evaluation of DRC mission from a social historical perspective, but stresses that much more research is needed before any conclusive evaluation can be attempted.

Die Ned Geref Kerk het ' $\mathrm{n}$ trotse sendinggeskiedenis in Suidelike en Sentraal-Afrika. Dit is ' $n$ stelling wat sonder vrees vir te veel teenspraak gemaak kan word. Die feit dat dit 'n trotse rekord genoem kan word, beteken natuurlik nie dat dit sonder foute en tekortkominge was nie. Dit is juis een rede waarom die bestudering van die geskiedenis so belangrik is: om ' $n$ betroubare rekord te hê, maar ook om te leer uit foute en tekortkominge met die oog op sendingbetrokkenheid in die hede en toekoms. Die Ned Geref Sendinggeskiedenis is redelik uitvoerig geboek-

1 Die keuse van die titel is " $n$ bewuste sinspeling op die titel van ' $n$ bekende Ned Geref sendingblad: Op die Horison. 
staaf, minstens ten opsigte van die "bruta facta"2. Daar is egter een belangrike dimensie waarin die geskiedskrywing van die Ned Geref sending nog te kort skiet, en dit is ten opsigte van ' $n$ analitiese sosiale sendingeskiedenis. Aangesien die begrip sosiale sendinggeskiedenis nie groot algemene bekendheid geniet nie, is dit waarskynlik nodig dat ek heel eerste verduidelik wat ek daaronder verstaan, en ook aandui waarom ek so ' $\mathrm{n}$ benadering as waardevol en nuttig beskou.

\section{BEGRIPSOMSKRYWING}

Ek reken dat dit noodsaaklik is dat ek my siening van 2 begrippe baie kortliks verduidelik: sendinggeskiedenis en sosiale sendinggeskiedenis. Ek hoef sekerlik nie die reg tot bestaan van sendinggeskiedenis te probeer regverdig nie; ek moet wel verduidelik wat ek onder die begrip verstaan. Die eerste kontroversiële kwessie is die verhouding tussen sendinggeskiedenis en kerkgeskiedenis. Ekself sien geen rede om onderskeid tussen die twee te maak nie. Die kerk van Jesus Christus is missionêr in sy diepste wese, en die geskiedenis van die Christelike gemeenskap se bestaan in die wêreld is ten diepste sendinggeskiedenis. Of ' $n$ mens dan praat van kerkgeskiedenis of sendinggeskiedenis hang myns insiens af van die klem wat ' $\mathrm{n}$ mens wil plaas of die fokuspunt van waaruit jy na die gegewens wil kyk. Die breëre kontrovers is dan vervolgens of kerkgeskiedenis in een of ander vorm prinsipieel te skei is van wêreldgeskiedenis/sekulêre geskiedenis. Na my mening vul kerkgeskiedenis een van die rubrieke in die wye spektrum van menslike geskiedenis, ' $n$ uiters belangrike en unieke rubriek, en daarom te onderskei maar nie te skei nie. As Christene het ons eenmaal net een bestaan aan hierdie kant van die wederkoms, en dit is ' $n$ bestaan in die wêreld. Daarby verstaan ek die roeping tot ' $n$ lewe in navolging van Jesus die Messias as ' $\mathrm{n}$ lewe wat my oproep tot betrokkenheid, mededeelsaamheid, selfs solidariteit, met die lewe van die mense vir wie God oneindig liefhet. Ek leef hopelik uit ' $n$ ander motivering, met " $n$ gans ander toekomsverwagting, maar my geskiedenis (en die geskiedenis van die Christelike gemeenskap as geheel) is volledig deel van die geskiedenis van die menslike gemeenskap. Daar is ' $\mathrm{n}$ verdere kwalifikasie wat ek wil uitwys ten opsigte van dit wat ek in hierdie artikel doen. Ek skryf die "storie" hier bewustelik vanuit die gesigspunt van die sendende kerk (die Ned Geref kerk), aangesien dit gaan oor die sosiale konteks spesifiek van

2 Dit sou inderdaad ' $n$ onmoontlike taak wees om in die bestek van ' $n$ enkele artikel uitvoerig na die bronne te verwys. Daarom het ek gekies om slegs te verwys na 2 bekende, semi-offisiële bronne: die 2 volumes van Aan God die dank, geskryf deur Dr J M Cronjé en Prof D Crafford onderskeidelik, en gepubliseer deur ISWEN in die vroeë tagtigterjare van die vorige eeu. Albei bevat ruim verwysings na beskikbare bronne. 
die sendelinge. Daar is deesdae tereg ' $n$ sterk bewussyn dat sendinggeskiedenis in die verlede te veel geskryf is slegs vanuit die gesigspunt van die sendelinge, sonder behoorlike inagneming van die interaksie met die ontvangers van die boodskap. My gesigspunt in hierdie artikel is egter doelbewus die wisselwerking tussen sendingmotivering en sosiale konteks(te). Dit handel met ander woorde grotendeels oor die "storie" wat afspeel nog voordat die sendelinge op die "sendingveld" land. Daar is dus nog nie werklik sprake van interaksie met " $n$ ontvangende gemeenskap nie.

Die begrip sosiale sendinggeskiedenis lei ek af van die begrip sosiale geskiedenis/geskiedskrywing. Die begrip het volgens Hobsbawm (1974:2-3) veral algemene aanvaarding verwerf sedert die 1950s (hoewel hy waarsku dat "its best practitioners have always felt uncomfortable with the term itself" 1974:5). Dit het volgens hom gegroei uit historiese analises wat veral gerig was op die geskiedenis van sosiale bewegings onder armes, geskiedenis gefokus op gebruike en handelswyses in die alledaagse lewe (iets soos "kultuurgeskiedenis"), en sosiale geskiedenis as ekonomiese geskiedenis. Sosiale geskiedenis as akademiese spesialiseringsrigting is daarom redelik jonk, maar het die afgelope halfeeu ' $\mathrm{n}$ groot opbloei beleef. Volgens Hobsbawm (1974:4) het hierdie opbloei veral saamgehang met

"the immense significance of the revolutions and struggles for political and economic emancipation of colonial and semi-colonial countries, which drew the attention of governments, international and research organizations, and consequently also of social scientists, to what are essentially problems of historic transformations".

Die relevansie van sosiale geskiedenis (en sosiale sendinggeskiedenis) ook en veral vir mense en institusies in Suider-Afrika is daarom voor die hand liggend. Nie alleen was die meeste lande in hierdie gebied kolonies of semi-kolonies nie, almal is ook nog steeds in diepgaande prosesse van sosiale transformasie betrokke.

Met sosiale geskiedenis wil historici (en ander sosiaal-wetenskaplikes, soos ekonome, antropoloë, teoloë, ensovoorts, die begrip is per definisie inter-dissplinêr) dan uitdrukking gee aan die oortuiging dat die bestudering van die geskiedenis meer behels as die studie van 'n begrensde of geïsoleerde gebeurtenis, tydvak of aspek van die verlede. Dit beklemtoon daarenteen ' $n$ beskouing van geskiedenis wat rekening hou met "die geïntegreerde aard van die samelewing en die onderlinge wisselwerking tussen die onderdele en die geheel" (Grundlingh 1987:33; vg1 ook Hobsbawm 1974:5). Dit hou rekening daarmee dat die wedervaringe van mense en samelewings bitter selde "sommer gebeur", maar dat dit veel eerder toegeskryf kan word aan die wisselwerking van strukturele 
magsverhoudinge (1987:34) ${ }^{3}$. Die basiese uitgangspunt is dus: "Culture does not exist apart from economic realities any more than it does from politics" (Vail in Grundlingh 1987:37). Dit is egter belangrik om in gedagte te hou dat "politiek" hier nie verwys na die konvensiële betekenis van partypolitiek of die praktiese politieke twispunte van ' $n$ besondere land of streek nie. Die woord word in die sosiale geskiedenis veel meer verstaan in die algemene sin van "politieke ekonomie", oftewel in Grundlingh (1987:34) se woorde: "die basiese ekonomiese ordeningsbeginsel in die samelewing en die uitwerking daarvan op die verspreiding van rykdom en mag". Daar is heelwat voordele verbonde aan so " $n$ benadering tot die geskiedenis. So gee dit uitdrukking aan die holistiese aard van menslike lewe waarvan godsdiens ' $n$ integrale dimensie vorm; dit is uit die aard van die saak interdissiplinêr in benadering en beoefening; en dit bied veel beter as enige ander benadering ruimte om die belangrike bydrae van "die vergete 'gewone mense' van die verlede" (Grundlingh 1987:37) te verdiskonteer". Dit lyk vir my dus voor die hand liggend dat daar belangrike winspunte vir teologie en missiologie te vind is in die skryf van die sendinggeskiedenis ook vanuit hierdie gesigspunt ${ }^{5}$. Die Christelike evangelie is immers nie iets esoteries en "bowe-aards" nie; dit is "n geheel konkrete boodskap vir konkrete mense in hul alledaagse lewe. Die sosiale, politieke, ekonomiese en ander grenslyne wat hul daaglikse lewe afbaken is dus essensiële faktore wat

3 "Daar kan nie werklik sprake van geïntegreerde sosiale geskiedenis wees indien die onderdele nie met die geheel verbind word nie; sosiale gegewens uit die verlede word eers werklik betekenisvol wanneer dit binne " $\mathrm{n}$ breër raamwerk geplaas word" (Grundlingh 1987:39).

4 "Volwaardige sosiale geskiedskrywing vereis onder andere dat daar met " $n$ sensitiewe oor geluister word na die verskeidenheid stemme vanuit die laer klasse uit die verlede; dat die navorser oor die vermoë beskik om hom op ' $n$ verbeeldingryke wyse, sonder om te romantiseer, in die plek van andere te plaas wie se lewensopvattinge en waardes totaal van syne mag verskil; dat hy die aard en wese van sosiale protes en konflik, wat dikwels ' $\mathrm{n}$ integrerende deel van verhelderende sosiale geskiedenis vorm, deeglik moet deurgrond; en dat hy boonop die verbande tussen sy bepaalde tema en die sosio-ekonomiese asook politieke konteks oortuigend moet aantoon" (Grundlingh 1987:46).

5 Die "ook" hier is baie bewustelik gekies. Ek bedoel met ander woorde nie dat sosiale sendinggeskiedenis nou die enigste kategorie sendinggeskiedenis moet word nie. Ek reken eerder dat dit ' $n$ lewensbelangrike bykomende gesigspunt bied waarsonder ons die totaliteit van die sendinggeskiedenis nie voldoende kan begryp nie. Soos Hobsbawm (1974:7) tereg opmerk, moet ons waarskynlik nie te veel verwag van sosiale geskiedenis nie, aangesien dit ons dikwels nie meer kan verskaf nie as "useful metaphors, concepts, or terms (such as 'role'), or convenient aids in ordering our material". 
' $n$ invloed uitoefen op die geloofskeuses wat hulle maak ${ }^{6}$. Die lewensen wetenskapsbenadering inherent aan sosiale geskiedskrywing neem hierdie realiteite uit die staanspoor in berekening en help ons dus om ' $\mathrm{n}$ lewens- en werklikheidsgetroue sendinggeskiedenis te skets. Die skryf van ' $n$ sosiale sendinggeskiedenis sou ons as missioloë ook help om die haas onoorbrugbare kloof tussen die bestudering van kerk/sendinggeskiedenis en onderwerpe van belang vir "sekulêre geskiedskrywers" te oorbrug (cf Elphick 1992:183) en sodoende gehoor te gee aan Elphick (1987:190) se ernstige oproep,

"to study the substance and inner logic of past religious consciousness, its 'otherworldly' side included; but then to situate this consciousness in 'mainstream' history, to make appropriate connections to contemporary events and socio-economic structures".

So " $\mathrm{n}$ geheelprentjie van die Suid-Afrikaanse geskiedenis is nodig vir beide "sekulêre" geskiedskrywers sowel as vir missioloë en ander sosiaal-wetenskaplikes, want, soos die Comaroffs (1991:xiv), in navolging van Monica Wilson, verklaar: “... it is impossible to understand the past or the present in South Africa without taking into account the salience of religion - especially evangelical Christianity"7.

\section{NED GEREF SENDING: 'N DWARSSNIT 1934 TOT 1961}

Dit is uit die aard van die saak ' $\mathrm{n}$ onbegonne taak om in die bestek van een artikel ' $n$ volledige sosiale sendinggeskiedenis van die Ned Geref kerk te probeer skryf. Daarom sou ek eerder ' $n$ dwarssnit van ' $n$ kort periode wou maak om as ' $n$ gevallestudie te dien van wat met so ' $n$ sosiale sendinggeskiedenis beoog sou kon word". In 'n sosiale sending-

6 Ek noem slegs 2 bronne wat as basis dien vir hierdie stelling. Op grond van ' $n$ sosio-teologiese studie oor die maniere waarop lidmate van Pinksterkerke en Basisgemeenskappe (CEBs) in Brasilië armoede hanteer en verwerk, konkludeer Mariz (1994:1): "Economic conditions and material lifestyles have direct conesquences for the beliefs people adopt... it is important to understand the material conditions of people's lives in order to understand their beliefs". En nader tuis toon Watt (2001:528 ; 136-137) onteenseglik die verband aan tussen suksesvolle Pinkstersending en armoede, sosiale ontwrigting en magteloosheid.

7 Indien daar lesers is wat in ' $n$ wyer bespreking belangstel, vergelyk Brown \& Van Keuren (1991) en Flinn \& Smout (1974).

8 Gegewe die realiteit dat hierdie niks meer is as ' $n$ verkennende dwarssnit nie, wil ek daarop wys dat ek nie in staat is om "die stemme van vergete 'klein' mense" (sien voetnoot 4 hierbo) tot hul reg te laat kom nie. Daarvoor is intense studie van primêre bronne soos briewe, pamflette, verhale, ensovoorts, nodig - iets wat ek nie hier beplan of kan doen nie. Daar word hoofsaaklik na die "groot" stemme van gepubliseerde bronne geluister. Ek glo egter dat ons nogtans " $n$ idee kan vorm van wat met ' $n$ sosiale sendingstudie beoog en bereik kan word. 
geskiedenis word die periodisering bepaal deur belangrike ontwikkelinge in die sosiale, politieke en ekonomiese geskiedenis. Die keuse van ' $n$ periode is vir die doelwit van hierdie artikel uit die aard van die saak willekeurig, en ek het besluit op die periode 1934 tot 1961. Daar is egter wel logiese redes waarom ek hierdie periode uitlig. In die eerste plek: die begin- en einddatums.

Belangrike omwentelinge het plaasgevind in Suid-Afrika sedert die middel van die dertigerjare van die twintigste eeu. Die ernstige droogte en ekonomiese depressie van die twintiger- en dertigerjare het geweldige ontwrigting tot gevolg gehad, veral onder (plattelandse) Afrikaners (wat natuurlik verreweg die meerderheid van Ned Geref lidmate uitgemaak het). Die tydperk is veral gekenmerk deur grootskaalse verstedeliking en verarming ${ }^{9}$. Een belangrike respons tot hierdie krisis is die belangrike ekonomiese organisasie en ontwikkeling geïnisieer veral deur verskeie Afrikaanse organisasies soos die (Herenigde of Gesuiwerde) Nasionale Party, die Afrikanerbroederbond, en organisasies onder hulle beheer sedert 1934 (vgl O’Meara 1983:1-3). Teen die middel van die dertigerjare het die idee ook posgevat van ' $n$ simboliese ossewa-trek om die eeufees van die Groot Trek te herdenk. Hierdie gebeurtenis sou uiteindelik in 1938 plaasvind, en het gelei tot grootskaalse kulturele en politieke mobilisasie onder Afrikaners, wat uiteindelik direk verbind kan word met die politieke oorwinning van die Nasionale Party in 1948. Vandaar die keuse van my aanvangsdatum. In 1961 het die Unie van Suid-Afrika ontbind en is omskep in die Republiek van Suid-Afrika. Dit was die bereiking van 'n baie langgekoesterde Afrikanerideaal, en het 'n nuwe politiek-ekonomiese tydperk in Suid-Afrikaanse geskiedenis ingelui. Vandaar die keuse van my einddatum.

Hierdie periode oorvleuel ook met ' $\mathrm{n}$ tydperk van belangrike ontwikkeling in die Ned Geref Kerk. Na die Kaapse hofuitspraak van 1862 wat kerkeenheid tussen die Kaapse sinode van die Ned Geref kerk en die Voortrekkergemeentes in die binnelandse provinsies verbied het, het die verskillende provinsiale/streeksinodes apart gefunksioneer en beleid bepaal. In 1907 is die (federale) Raad van die Ned Geref Kerke gevorm ter wille van skakeling en die koördinasie van gesamentlike aksies. Die Raad het in 1925 'n staande kommissie vir naturellesake in die lewe geroep, wat onder andere in 1934 besluit het om ' $n$ eenvormige sendingbeleid vir die verskeie sinodes op te stel. Hierdie beleid is in 1935 aanvaar en na aanvaarding deur die onderskeie sinodes, het dit die aanvaarde sendingbeleid van die Ned Geref kerk geword (Crafford

9 Deist (1990:127-128) verskaf getalle en ontledings wat die omvang hiervan aandui. 
1982:463-464) ${ }^{10}$. Ons kan dus sedert 1935 praat van ' $n$ eenvormige Ned Geref sendingbeleid - ' $n$ baie belangrike gegewe in enige historiese analise. In 1962 het die eerste vergadering plaasgevind van die Algemene Sinode van "n ("herenigde") Nederduitse Gereformeerde Kerk. Nou kom daar ook ' $n$ Algemene Sinodale Sendingkommissie tot stand, wat in die toekoms sendingbeleid vanuit ' $\mathrm{n}$ sentrale kantoor sou bepaal en koördineer. Daarmee breek ' $n$ kwalitatief nuwe tydperk vir die Ned Geref sending aan (Cronjé 1981:385).

' $n$ Laaste opmerking in verband met die periode wat ek gekies het: my bedoeling is gladnie om ' $n$ chronologies-volledige weergawe van die sendinggeskiedenis gedurende hierdie jare te gee nie. Soos ek reeds vroeër opgemerk het, is daar verskeie bronne waarin die feitelike gebeure van die geskiedenis opgeteken is. Dit gaan vir my hier veel meer om die uitwys van tendense, die opsporing van moontlike oorvleueling tussen gebeure in die sosiale, ekonomiese, kulturele, godsdienstige en politieke domeine. My benadering is dus per definisie selektief.

\subsection{Sending en politieke kultuur ${ }^{11}$}

' $n$ Besonder interessante aspek van die Sendingbeleid van 1935 is die weerspieëling van wat waarskynlik genoem kan word breë konsensusdenke onder wit Suid-Afrikaners (oftewel wit politieke kultuur) ten opsigte van die hantering van wat algemeen genoem is die "naturellevraagstuk" ". Sedert 1925 het die Raad van Ned Geref Kerke "n staande Kommissie vir Naturellesake gehad. Die subkommissie van die Raad wat die sendingbeleid geformuleer het, het dit gedoen spesifiek in samewerking met hierdie kommissie. In 1938 besluit die Raad dat 'n Federale

10 Die beleid is te vinde in, onder andere, Gerdener 1958:269-275.

11 Die uitdrukking "politieke kultuur" het hier vir my ' $n$ spesifieke betekenis. Dit gaan vir my nie om die spesifieke politieke beleid van een of ander politieke party nie. Dit gaan vir my veel eerder om ' $n$ algemene benadering wat deur baie wit SuidAfrikaners gehuldig is ten opsigte van "Naturellebeleid" of die "rassekwessie" algemeen beskou as dié sentrale vraagstuk in die ordening (polities, ekonomies, sosiaal, ens.) en enige beoogde transformering van die Suid-Afrikaanse samelewing. Daar was verseker kleiner verskille in benadering en praktyk, maar my kontensie is dat "separatisme" en "voogdyskap" die oorkoepelende benadering van alle wit partye uitgedruk het. Dit is hierdie gemeenskaplike oortuging/benadering wat ek wil uitdruk met die konsep "politieke kultuur".

12 Crafford (1982:464) maak spesifiek daarvan melding dat daar in die 1920s en 1930s nog " "n redelike mate van eenstemmigheid" bestaan het oor die "Naturelle Kwessie" by al die vernaamste Protestantse kerke (wie se beleid natuurlik in daardie jare deurgaans bepaal is deur wit kerkleiers en -administrateurs). Terloops, dis insiggewend dat daar nooit gedurende die Suid-Afrikaanse geskiedenis sprake was van " $n$ "blankevraagstuk" nie! Was witmense altyd net "deel van die oplossing" en swartmense altyd net "deel van die probleem"!? 
Sendingraad van Ned Geref Kerke in die lewe geroep moet word, wat uiteindelik in 1942 gekonstitueer is. Die Federale Sendingraad het die werksaamhede van die Kommissie vir Naturellesake oorgeneem. Afgesien van hierdie direkte koppeling in wordingsgeskiedenis, weerspieël die sendingbeleid ook duidelik die heersende wit politieke denke ten opsigte van teenstand teen rassevermenging, afsonderlike ontwikkeling van "volke", ensovoorts (cf Crafford 1982:464-465; Cronjé 1981:385; Gerdener 1958:36, 269-275). Daar is dus ' $n$ sin waarin Ned Geref sendingbeleid sinoniem was met gangbare "naturellebeleid". Natuurlik was die "oplossing van die naturellekwessie" geensins die enigste Ned Geref sendingmotivering en -doel nie - "n blote verwysing na die tradisie en nalatenskap van Dr Andrew Murray junior is al genoeg om so ' $n$ simplistiese verklaring te weerlê. Aan die ander kant kan dit nie ontken word nie dat Ned Geref sendingbeleid duidelik heel gemaklik in die dampkring van wat ek wil noem die oorheersende wit politieke kultuur geformuleer is. Dit is natuurlik ' $n$ aanduiding van die gangbare opvatting dwarsoor die wêreld in daardie jare dat sending iets is wat deur witmense vir of aan swartmense gedoen word. Dit is egter ook 'n aanduiing van die baie noue simbiose wat in Suid-Afrika ontwikkel het tussen sendingdenke en politieke denke. Dit is myns insiens belangrik om uit te wys dat hierdie simbiose nie net bestaan het tussen die Nasionale Party en die Ned Geref Kerk nie. Soos uit die voorafgaande blyk, was dit reeds ' $n$ werklikheid lank voor die bewindsaanvaarding van die Nasionale Party. Daarby is dit ook nie "n "kwaal" waaraan net die Ned Geref sending gely het nie. Gedurende die negentiende eeu, en seer sekerlik nog teen die 1930s en 1940s, was dit vir kerke en sendinggenootskappe heel natuurlik om nou met die regering van die dag saam te werk in die beplanning en uitvoering van hul sendingwerk. Dit het veral tot uitdrukking gekom in die begrip "manifest destiny" wat ten opsigte van Westerse meerderwaardigheid gebruik is, en het sy hoogtepunt bereik gedurende die periode van vervlegting van sending en kolonialisme (vgl veral Bosch 1991:298-313). Die feit dat meeste kerke en sendinggenootskappe daaraan skuldig was, is natuurlik op die ou einde toeligting maar geen verontskuldiging nie. Dit is daarom hoog nodig dat hierdie oorvleueling van sendingbeleid en heersende politieke kultuur (veral gedurende hierdie vormgewende periode in Suid-Afrikaanse geskiedenis) erken word as ons tot ' $\mathrm{n}$ gebalanseerde oordeel wil kom oor die suksesse en mislukkings van Ned Geref sending in Suid-Afrika.

Dit is ook wel so dat na die bewindsaanvaarding van die Nasionale Party Ned Geref sendingbeleid en heersende politieke kultuur dermate oorvleuel het dat dit waarskynlik vir buitestaanders moeilik was om aan te dui waar die een ophou en die ander begin. Ter bevestiging van hierdie stelling wil ek verwys na die hele situasie rondom die publikasie van 
die Tomlinson-verslag (Tomlinsonverslag 1954) ${ }^{13}$. Hierdie verslag het aan die lig gebring dat daar 'n baie ernstige behoefte bestaan het aan sosiale, ekonomiese, opvoedkundige, en ander vorme van ontwikkeling in die reservate. Dit het ook aan die lig gebring dat die Ned Geref Kerk ' $n$ groot agterstand gehad het teenoor ander kerke, dikwels oorsese of Engelstalige Suid-Afrikaanse kerke, in die opbou van gemeentes en verskaffing van algemene sendingkundige dienste in die reservate. Interessant genoeg het die publikasie van die verslag (dit is deur middel van allerlei seminare en kongresse wyd bekendgestel) gelei tot 'n geweldige opbloei in sendingroepings onder Ned Geref lidmate. So verklaar Prof Gerdener (1958:220) byvoorbeeld dat die getal sendingroepings onder teologiese studente toegeneem het van $10 \%$ tot $30 \%$ van die totale getal studente, direk as gevolg van die invloed van die Tomlinson-verslag ${ }^{14}$. In ' $n$ situasie soos hierdie is dit baie moeilik om die oorvleueling van sendingmotivering en politieke kultuur in die opbloei van sendingentoesiasme te ontken ${ }^{15}$ (vgl ook Saayman 2001). Die oorvleueling het egter nie net gegeld ten opsigte van sendingmotivering nie; sendingbeleid was sekerlik ook ter sprake. So word dan ook uitdruklik in die Tomlinsonverslag (1954:161) verklaar:

"Die kerk en staat vorm in Suid-Afrika nie ' $n$ antitese nie. Inteendeel, die een is spanmaat van die ander. In Suid-Afrika is hulle beslis die een op die ander aangewese, veral wat die geestelike en tydelike opheffing van die Bantoe betref. Goeie sendingbeleid is goeie staatsbeleid in Suid-Afrika. Dit vorm die basis van ' $n$ gesonde rassebeleid".

13 Die Tomlinsonkommissie is in 1950 deur die NP-regering aangestel om die sosio-ekonomiese ontwikkeling van die "Bantoe-reservate" (toe nog nie tuislande genoem nie) te ondersoek. Dit is interessant en belangrik om daarop te let dat ' $n$ belangrike impuls tot die aanwysing van die Tomlinsonkommissie gekom het via ' $n$ besluit van die Kerkkongres van 1950 dat by die regering aanbeveel word om " $n$ kommissie van ondersoek te benoem insake die "oplossing van die naturellevraagstuk" (vgl Truter 1995:43-44). Die Tomlinsonverslag is in 1954 gepubliseer en bibliografiese gegewens verskyn in my bibliografie. Vir verdere besonderhede en bespreking van die Tomlinsonverslag, sien Gerdener 1958:218vv, Truter 1995, en Saayman 2001.

14 Dit is insiggewend dat die kommissie self die kerke opgeroep het tot "mobilisering" en " $\mathrm{n}$ "intensiewe sendingveldtog in hul geledere" wat selfs in sekere detail uitgespel is (Tomlinsonverslag 1954:156).

15 Dit is interessant om daarop te let dat die Tomlinsonverslag (1954:16) self verklaar dat "in die afgelope twee dekades van Blanke kant ' $n$ intense belangstelling in die studie van die allesoorheersende bestaansvraagstuk [die Naturellevraagstuk] ontwikkel het". Dit bevestig myns insiens ook die oorvleueling tussen sendingentoesiasme en politieke kultuur. 
As die Kommissie dan by die aanbieding van sy ontwikkelingsvoorstelle stuit teen die groot en moeilike probleem hoe swartmense gemotiveer sou kon word om heelhartig aan die programme deel te neem, stel hy voor dat juis die Christelike godsdiens (deur middel van die sending) die aangewese weg is om ' $n$ oplossing te vind. Dat dit oor meer as blote sosio-ekonomiese ontwikkeling gaan, word myns insiens duidelik as die Kommissie met goedkeuring aanhaal uit gelewerde getuienis: "The only safeguard for European civilization in South Africa is an intensified effort to evangelise the non-Christian" (Tomlinsonverslag 1954:155). Dit kom dan nie eintlik as " $n$ groot verrassing nie dat leiers van die Nasionale Party "die gaping gesien het", en spoedig probeer het om sending in te span vir die meer doeltreffende uitvoering van politieke beleid. Minister De Wet Nel, voormalige lid van die Tomlinsonkommissie, en op daardie stadium Minister van Naturellesake, het byvoorbeeld in 1958 gesê (aangehaal in Bosch 1985:68):

"An aspect which... is one of the main reasons why many people are still cold and indifferent to mission work, is its political significance.... If the Afrikaans churches succeed in bringing the blacks over into a Protestant-Christian context, South Africa will have a hope for the future. If this does not happen, our policy, our programme of legislation and all our plans will be doomed to failure... Our sons and daughters should realise that mission work offers the most wonderful opportunity to serve God, but also the most glorious opportunity to serve the Fatherland".

Waar die simbiose tussen sending en die heersende politieke kultuur so eng raak, behoort die gevaarligte natuurlik helder aan te gegaan het ${ }^{16}$. Dit het egter, op enkele uitsonderings $\mathrm{na}^{17}$, nie gebeur nie. Trouens, as ek myself as voorbeeld moet neem, sou ek reken dat die meeste Ned Geref sendelinge en -sendingwetenskaplikes hul daaglikse werksaamhede voortgesit het in die eerlike (maar naïewe - hieroor later meer) oortuiging dat hul net hul roeping van die Here gehoorsaam het en niks met politiek te doene gehad het nie ${ }^{18}$.

16 Teen die einde van die vyftigerjare van die vorige eeu was daar al baie literatuur beskikbaar in verband met die gevare verbonde aan so ' $n$ noue verknoping van sendingbeleid en politieke beleid. Die uitstaande voorbeeld hiervan, en ' $n$ bron wat sekerlik in teologiese en missiologiese kringe in Suid-Afrika bekend was, is Hoekendijk se Kerk en volk in de Duitse Zendingswetenschap (Hoekendijk 1948).

17 'n Missioloog wat wel gewaarsku het, was Willem Krige met sy doktorale proefskrif oor Die probleem van eiesoortige kerkvorming by Christian Keysser (Krige 1954). Vergelyk ook my evaluering van Krige se standpunt in Saayman (1993).

18 Ek was vanaf begin 1966 tot einde 1968 sendingonderwyser in Zambia, en was totaal oorbluf toe die skoolkinders ons sendelinge beskuldig het van versteekte poli- 


\subsection{Sending en volksdiens}

Hierdie onderwerp sluit natuurlik nou aan by die voorafgaande, maar na my mening is daar wel ' $\mathrm{n}$ duidelike onderskeid. Ek het verduidelik dat ek met "politieke kultuur" verwys na algemene politieke consensusdenke onder wit Suid-Afrikaners oor "n lang tydperk. Met "volksdiens" verwys ek egter nou spesifiek na diens aan en verbintenis met die Afrikanervolk $^{19}$, die belangrikste voedingsbodem van Ned Geref kerk en sending, spesifiek gedurende die tydperk onder bespreking (wat die tydperk was van vestiging en konsolidering van Afrikaners se politiek-ekonomiese mag - vergelyk O’Meara 1983). David Bosch (1985:65-67) redeneer oortuigend dat die Ned Geref Kerk tot en met die Tweede Anglo-Boereoorlog (1899-1902) grotendeels beskryf kan word as kerk van die "establishment", en nie kerk van die volk nie. Die traumatiese ervarings rondom die oorlog het egter ingrypende verandering gebring, en voortaan sou die Ned Geref Kerk werklik die kerk van die Afrikanervolk genoem kon word, vir die volgende vyf en veertig jaar meestal in teenstand teen die "establishment". Dit sou veral duidelik word in die groeiende polarisasie in Afrikanergeledere tussen die volgelinge van respektiewelik Generaals Hertzog, Smuts en Dr Malan ${ }^{20}$. Dit bereik ' $n$ hoogtepunt in die woelinge rondom die Smuts-regering se besluit om aan Engeland se kant tot die Tweede Wêreldoorlog toe te tree. Met die oorwinning van die (Gesuiwerde of Herenigde) Nasionale Party in 1948 verval die instelling van teenstand teen die "establishment" egter grotendeels, omdat die Ned Geref Kerk gevoel het dat die politieke beleid van die NP grotendeels

tieke bymotiewe. Ek kan eerlik sê dat dit die reaksie was van al my mede-sendelinge. Ek is egter daarvan bewus dat hierdie ' $n$ gevaarlike veralgemening kan wees. Ek wil die stelling dus in twee opsigte kwalifiseer: (i) Dit is ' $n$ impressionistiese stelling, en moet deur behoorlike navorsing reg of verkeerd bewys word; (ii) Ek beskou naïwiteit nie as genoegsame verontskuldiging nie. Soos ' $n$ NP-politikus gedurende die werksaamhede van die WVK opgemerk het: somtyds sê mense: "Ons het nie geweet nie", terwyl die waarheid eintlik is: "Ons wou nie weet nie".

19 Die verbintenis tussen sending en die Afrikanervolk het lank voor hierdie tyd reeds bestaan. By 'n Sendingdag op Stellenbosch (26 Oktober 1883) het Prof Marais van die Kweekskool byvoorbeeld die sending gekarakteriseer as "die ware Afrikaanse saak, wat te veel verwaarloos word en te min gewaardeer word" (in Louw 1965:40) - kur-sief in die oorspronklike.

20 Met hierdie stelling weerspreek ek nie my argument in die vorige afdeling nie. Daar was sekerlik belangrike aksentverskille tussen genoemde drie Afrikanerleiers, maar as oorkoepelende standpunt het hul aldrie segregasie/separatisme/afsonderlikheid as leidende beginsel in rassebeleid onderskryf. So byvoorbeeld loof Minister De Wet Nel Generaal Hertzog as die grondlegger van die beleid van "Afsonderlike Ontwikkeling" (in Truter 1995:11). 
versoenbaar was met die wil van God en die ideale van die kerk $^{21}$. In dermate dat die Ned Geref Kerk sigself bewustelik geïdentifiseer het as kerk van die Afrikaner (soos dit gedurende die periode onder bespreking gedoen is), is dit te verwagte dat (minstens " $n$ mate van) verwarring kon bestaan tussen sending as deelname aan die missio Dei en as diens aan die volk $^{22}$. Truter (1995:15-16) haal verskeie uitsprake aan van Ned Geref sendelinge en predikante op grond waarvan hy verklaar dat Ned Geref sending "ook (miskien veral)" gegaan het om die behoud van die wit Afrikanervolk. Gegewe aansprake van politieke leiers soos Minister De Wet Nel (vgl die vorige afdeling), die uitsprake van sendelinge en leraars (deur Truter aangehaal), en die simbiose tussen sendingbeleid en staatsbeleid soos dit uitdrukking gevind het in die Tomlinsonverslag, voel ' $\mathrm{n}$ mens geneig om Truter toe te gee dat sending feitlik volledig opgegaan het in volksdiens. Persoonlik voel ek egter dat ' $n$ meer genuanseerde evaluering waarskynlik nader aan reg is. Op grond van ' $n$ kort eie ontleding van die Tomlinsonverslag en sy nagevolge (Saayman 2001) kom ek tot die gevolgtrekking dat sendingentoesiasme (gebore uit ' $\mathrm{n}$ "suiwer" sendingmotivering ${ }^{23}$ ) vanweë kontekstuele omstandighede hopeloos verstrengel geraak het met rassisme en etnosentriese oorwegings. Sommige (sendelinge en nie-sendelinge) het ongetwyfeld die verstrengeling vir selfsugtige oorwegings uitgebuit. (Daarom is Truter [1995:16] wel korrek wanneer hy beweer dat die opbloei van sendingentoesiasme gedurende die jare 1948-1954 " $n$ integrerende deel was van "n selfreddingspoging" deur die Afrikaner). Andere is egter waarskynlik beweeg deur ' $n$ opregte (maar heelwaarskynlik naïewe en misleide ${ }^{24}$ ) sending-

21 Vir enkele bronne ter stawing van hierdie stelling, sien byvoorbeeld Deist (1990: 134-135) en Truter (1995:12-14).

22 Dat dit ' $n$ wesenlike gevaar was wat inderdaaad sy uitwerking gehad het in die lewe van leidende sendelinge, word duidelik as ' $n$ mens byvoorbeeld die verhaal lees van Andrew Louw van Morgenster (Zimbabwe) se sendingroeping. Die verminging van ' $n$ sterk evangeliseringsdrang met ideologiese etnosentriese aansprake in verband met die rol van die Afrikaner in Afrika is baie duidelik in die relevante gedeelte van sy biografie (Louw 1965:40-41). Hoewel hierdie gebeure plaasgevind het baie jare voor die periode onder bespreking, sou ek wou redeneer dat dit as gevolg van sosio-politieke omstandighede gedurende hierdie periode waarskynlik baie sterker gefigureer het.

23 Waar ek sendingmotiewe kwalifiseer as "suiwer" en "onsuiwer" spreek ek nie "n morele waarde-oordeel uit nie (daarom die aanhalingstekens). Ek wil slegs aandui dat dwarsdeur die sendinggeskiedenis sending bedryf is uit ' $n$ groot mengsel van motiewe wat gewoonlik kontekstueel bepaal is, sodat dit vandag uiters moeilik is om ' $n$ enkelvoudige oordeel van suiwer of onsuiwer daaroor uit te spreek (vgl Bosch 1991:284-345).

24 Hierdie misleiding het moontlik gevloei uit die burgerlik-godsdientige verdraaiing van die Christelike geloof. So ' $n$ verdraaiing vind ons na my mening in die 
entoesiasme, miskien ook omdat hulle gedink het dat dit ' $\mathrm{n}$ groter fout sou wees om nie die nuwe geleenthede aan te gryp nie, ook al is dit op twyfelagtige manier geskep. Hierdie uiteindelik fatale vermen-ging van die motiewe, waarvolgens dit moeilik is om te onderskei tussen sending as missio Dei en sending as volksdiens, word goed uitgedruk deur die Kerkkongres van 1950 (angehaal in Truter 1995:38) wat konkludeer dat evangelieverkondiging (in die sending) tegelykertyd die hoofsaak is van sendingwerk, maar terselfdertyd ook die blywende oplossing vir die Suid-Afrikaanse rasseprobleem ( $\mathrm{m}$ a w die probleem van blanke oorlewing). Dit is na my mening die verste wat ' $n$ mens kan gaan in jou beoordeling van hierdie vervlegting. Skerper en meer indringende navorsing en ontleding (veral van die standpunte van individuele sendelinge) is nodig voordat ons tot ' $\mathrm{n}$ meer definitiewe oordeel kan kom oor sending en volksdiens. Die gevaarligte flikker egter baie duide-lik.

' $n$ Interessante aspek van sending-as-volksdiens (wat veral teen die einde van die periode onder bespreking sterk na vore kom) is die gees van optimisme waarin dit bedryf en gepropageer is. 'n Artikel van Professor A B du Preez van die Teologiese Fakulteit van Pretoria kan moontlik as voorbeeld hiervan dien (Du Preez 1960). Hy is van oordeel dat, as gevolg van verbeeldingryke politieke ontwikkeling in verband met die uitbou van afsonderlike "Bantoegebiede", die korrekte volkekundige benadering tot swartmense (in stamverband), en toegewyde uitbou van swart onderwys, daar "iets groots aan die gang is" wat kwalitatief verskil van enigiets wat vroeër gebeur het (1960:46-49). Daarom is Du Preez hoopvol dat die jaar 1960 inderdaad uiteindelik bekend mag staan as die begin van ' $n$ heel nuwe era in Suid-Afrika (1960:46). Wanneer ' $n$ mens die optimisme van ' $\mathrm{n}$ ingeligte en oortuigde voorstaander van die sending lees, en in ag neem in watter mate hy byvoorbeeld die onderwyssituasie misverstaan (hy verklaar dat die stelsel van Bantoeonderwys "met heelhartige instemming aanvaar word" - 1960:49), en toekomstige ontwikkelinge verkeerd voorspel, dan is ' $\mathrm{n}$ mens geneig om sending-asvolksdiens te sien as oëverblindery. Dit was immers maar " $n$ jaar voordat Sharpeville en Langa sou losbars en die era van gewapende stryd sou inlui, en in 1976 sou die massiewe verwerping van "Bantoeonderwys" deur swart leerlinge volg.

aanhef tot die (ou) Grondwet van die Unie en ook die latere Republiek van SA, wat verklaar dat die Almagtige God Christelike blankes met ' $n$ verhewe doel hier aan die suidpunt van Afrika geplaas het. Interessant is dit dan om daarop te let dat die Tomlinsonverslag (1954:161) juis hierdie aanhef aanhaal in 'n oproep tot kerk en staat (in simbiotiese eenheid) vir groter offers en toewyding aan die taak om die toekoms van die Christendom in Afrika te verseker. 


\subsection{Sending en Afrikanerprotes}

In die lig van die opmerking waarmee ek die vorige gedeelte afgesluit het, maak dit sin om die onderwerp van sending en Afrikanerprotes te opper. Die laaste gedeelte van die periode onder bespreking (veral die vyftiger- en sestigerjare) is naamlik ook gekenmerk deur al sterker uiting deur Afrikaners van afwysing en protes teen sosiale, ekonomiese en politieke ontwikkelings in Suid-Afrika (spesifiek rondom die teologiese sanksionering van apartheid). Die interessante kenmerk van hierdie afwysing en protes is die leidende aandeel wat persone vanuit kerklike, en spesifiek sendingkringe hierin geneem het. Die bekendste tweetal van die ouer garde was Professore Bennie Keet van Stellenbosch en Ben Marais van Pretoria. Keet het reeds in 1939 sy eerste waarskuwing laat hoor, maar dit was veral gedurende die veertigerjare dat hy en Marais al dringender gewaarsku het teen sosiale en politieke ontwikkelinge, die groeiende kloof tussen swart en wit, en die betrokkenheid van die Ned Geref Kerk hierby (Durand 1985:46). Volgens Durand (1985:46) is hierdie protes geïnspireer deur ' $n$ breër evangeliese benadering soos gereflekteer veral in die werk van Prof $J$ du Plessis van Stellenbosch. Du Plessis is natuurlik goed bekend vir sy intense sendingbetrokkenheid ${ }^{25}$. Dit was egter veral ' $n$ volgende geslag predikante en sendelinge wat uiteindelik bekendheid sou verwerf vir hul leidende aandeel in die klein maar groeiende protes teen die simbiose tussen staat en Ned Geref Kerk/ Sending ten opsigte van apartheid - mense soos Beyers Naudé, David Bosch, en Nico Smith om net enkele name te noem. Dit is " $n$ opvallende feit dat almal van hulle óf sendelinge was of " $n$ intense sendingbelangstelling gehad het, hoewel hulle in die "moederkerk" gedien het (vgl Durand 1985:47-49 en Saayman 1996:207-210) ${ }^{26}$. Die "sendingvleuel" van die Ned Geref Kerk is algemeen beskou as meer evangelies-piëtisties as die kerk in sy geheel (vgl Durand 1985). Ek stem saam met Durand (1985:48-49) dat wat algemeen beskou word as die grootste swakpunt in die piëtisme inderdaad in periodes van groot sosiale ontwikkeling en verandering inderdaad ' $n$ belangrike sterk punt kan wees, want

"the pietist will be less likely to justify his (sic) social actions by an appeal to unchanging biblical principles or to use the historical

25 Prof Marais se ervaring as Ned Geref afgevaardigde by die Tambaram Sendingkonferensie in 1938 het ook ' $n$ belangrike aandeel gehad in sy ontgogeling met Ned Geref rassebeleid (Durand 1985:46).

26 Een naam wat ek vroeër reeds genoem het, en nou weggelaat het, is dié van Prof Willem Krige. Sy proefskrif (Krige 1954) kan myns insiens. beskou word as die vroegste sistematiese protes teen apartheid in kerk en staat vanuit ' $n$ spesifiek missiologiese oogpunt. Hy was egter gedurende die vyftiger- en sestigerjare sendeling in Zambia en dus nie so intens betrokke by die debatte en argumente nie. 
situation in which he finds himself as a grid for biblical interpretation".

Die evangelies-piëtistiese agtergrond rebelleer dus makliker teen die identifisering van van ' $\mathrm{n}$ soiaal-politieke beleid met bybelse beginsels. Dus konkludeer Durand (1985:48-49) dat persone uit hierdie tradisie ' $n$ beter aanvoeling het vir die voortgaande ontwikkelingsprosesse in die geskiedenis as byvoorbeeld Kuyperiaans-Gereformeerdes. Laasgenoemdes is te geneig om die geskiedenis te wil indwing in " $n$ vorm gegiet uit "onveranderlike beginsels" wat na bewering uit God se skepping afgelei kan word. Dit is egter myns insiens nie net "groot grondbeginsels" en "denksisteme" wat hier aan die werk was nie. Persoonlike ervaring en belewenis van mense se werklike lewensomstandighede het ook ' $n$ belangrike rol gespeel. Evangelies-piëtistiese mense word dikwels gekenmerk deur ' $n$ sterk kommer oor die persoonlike verlossing van ander mense. Juis hierdie "anderwêreldse besorgdheid" bring piëtiste dan juis (in "hierdie-wêreldse" terme) baie naby aan die mense oor wie hulle besorg is. En dit bring hulle dikwels in kontak met sosiaal-ekonomiese kenmerke van daardie mense se lewe waarvan ander glad nie bewus is of wil wees nie. Na my mening is hierdie die deurslaggewende faktor wat juis sendelinge of sendingbetrokkenes die voortou laat neem het in protes teen politiek-ekonomiese ontwikkelinge in Suid-Afrika in die tydperk onder bespreking: "the concern for personal salvation, in a society characterised by the devastations of racism, led to an engagement with both personal and structural aspects of racism" (Saayman 1996: 210). Dit word duidelik geïllustreer in die lewe en werk van een van die protesterendes wat ek vroeër genoem het. As Nico Smith (2002:15-17) sy eie pelgrimstog, en die radikale veranderings waartoe dit hom gebring het, in sy eie woorde beskryf, doen hy dit onder die opskrif: "Entering a new context and being confronted by new questions". Toe hy vanweë sy evangeliese sendingoortuiging werklik naby aan swartmense gekom het deur in Mamelodi tussen hulle te gaan woon, toe moes hy sy siening aangaande die betekenis van missio Dei ingrypend verander (2002:16). Dit is nie nuwe teologiese insigte of ontdekkings wat hom hiertoe gebring het nie, maar gewoon alledaagse lewenservaring. Miskien sal dit dan ook uiteindelik een van die groot tragiese nalatenskappe van apartheid wees, dat dit so uitsonderlik suksesvol was om die wit wêreld en die swart wêreld so ver van mekaar te verwyder dat die daaglikse lewensnood van mense nie meer ' $n$ bepalende vormende rol kon speel in die uitwerking van politiek-ekonomiese beleid nie.

Soos dit so dikwels in die geskiedenis die geval is, kan ons dus nie ' $n$ netjiese eensydige oordeel uitspreek oor die betrokkenheid van die kerk by groot politiek-ekonomiese strominge in die wêreld nie. Ons word gelaat met ' $n$ ambivalente oordeel: ' $n$ kerk wat leef in simbiose met 
die heersende politieke kultuur, en wat sending amper fataal met volksdiens verwar, maar wat tog juis veral deur enkele sendelinge gewaarsku word teen die gevare van ' $\mathrm{n}$ onkritiese meedoen aan politiek-ekonomiese ontwikkelings.

\subsection{Belangrike areas vir verdere navorsing}

Ek het as subtitel gekies om te praat van "verkenning ten opsigte van " $\mathrm{n}$ sosiale sendinggeskiedenis". Doel van 'n verkenning is ook om areas aan te dui waar verdere navorsing nodig is, omdat die huidige stand van kennis te beperk is om tot enige sinvolle opmerkings te kom. Een so ' $\mathrm{n}$ area is die verband tussen sending en ekonomiese vermoëns. Dit is algemeen bekend dat die dertigerjare van die vorige eeu ook gekenmerk is deur die armblankevraagstuk. 'n Mens kan dus waarskynlik met sekerheid aanneem dat die meeste Ned Geref-gemeentes, veral in die Vrystaat en Transvaal, glad nie baie vermoënd was nie. Vir baie stadsgemeentes was dit waarskynlik 'n stryd om elke maand die begroting te laat klop. Tog is daar ' $\mathrm{n}$ sterk klem, sedert middel-dertigerjare, maar veral gedurende die veertiger- en vyftigerjare, op die gee ter wille van sendinguitbreiding (vgl bv Truter 1995:17, 20). Dit lyk inderdaad op eerste oogopslag asof die Ned Geref Kerk (veral) sending bedryf het vanuit gebrek (vgl Luk 21:1-4). Of is die teendeel waar, naamlik dat politieke mag juis toegang tot ekonomiese hulpbronne tot gevolg gehad het, en dit dus die al groter oorvloed was wat sending gemotiveer het $^{27}$ ? Vanuit die oogpunt van die sosiale sendinggeskiedenis moet hierdie korrelasie intensief ondersoek word.

' $\mathrm{n}$ Ander area wat verkenning verdien, is die verskuiwende fokus ten opsigte van "Sendingvelde". Dit is algemeen bekend dat die Ned Geref Kerk " $n$ sterk sendingroeping ervaar het in Afrika. Hierdie fokus was waarskynlik redelik konstant aanwesig tot die tagtiger/negentigerjare van die vorige eeu. Sedertdien het "die eindes van die aarde" (wat nooit heeltemal afwesig was in Ned Geref sendingdenke nie) sterker na vore getree. Die verskuiwende fokus hou heelwaarskynlik verband met die algemeen-menslike ervaring dat die wêreld voortdurend "kleiner" geword het gedurende die twintigste eeu, en onbekende areas en bevolkingsgroepe al duideliker onder die aandag kom. Dit is egter myns insiens belangrik om ook aandag te gee aan veranderende politiek-ekonomiese omstandighede in Suid-Afrika se verhouding met ander lande (spesifiek Afrikalande) en vas te stel watter invloed dit op die fokus op

27 In hierdie verband sal deeglik kennis geneem moet word van 'n sosio-ekonomiese analise soos byvoorbeeld dié van O'Meara (1983:119-178) om vas te stel in watter mate dieselfde ekonomiese mobilisasie in die Ned Geref Kerk aan die gang was. 
verskillende "sendingvelde" gehad het. Iets wat hiermee saamhang is die laat ontwikkeling van ' $n$ fokus op stadsending binne Suid-Afrika. Soos baie ander kerke, het die Ned Geref Kerk aanvanklik veral gekonsentreer op landelike en afgeleë gebiede (veral die reservate). Dit het waarskynlik onder andere saamgehang met die oorwegend plattelandse aard van Ned Geref lidmaatskap, sowel as die groter konsentrasies swartmense in landelike gebiede en reservate. Juis ook in die veertiger- en vyftigerjare van die vorige eeu het stadsending " $n$ opbloei beleef in terme van "garagedienste" en, ietwat later, "kampongsending". Watter politiekekonomiese faktore was hier aan die werk?

\section{SAMEVATTING}

Die Ned Geref Kerk het verlede jaar (2002) sy ouderdom bereken op 350 jaar. Dit is ' $n$ lang genoeg periode om sinvol tendense, golwings, hoogte- en laagtepunte in kerk en sending binne die sosiale, politieke en ekonomiese konteks, te kan onderskei. Die uiters beknopte verkenning wat ek hier onderneem het, bevestig myns insiens die noodsaaklikheid en belang van " $n$ behoorlike sosiaal-sendinggeskiedkundige ontleding. Selfs al sou die slotsom ten opsigte van die areas wat ek probeer verken het nie revolusionêr nuwe resultate aan die lig gebring het nie, is die aanduidinge (ook van areas wat nog bestudeer behoort te word) waarskynlik belowend genoeg om die noodsaaklikheid van 'n sosiale Ned Geref sendinggeskiedenis te bevestig. ' $n$ Blote feitelike en chronologiese weergawe van wat wanneer gebeur het en wie daarby betrokke was, kan baie maklik tot eensydige en foutiewe evaluerings lei. Om slegs een voorbeeld te noem: vir sy aandeel aan die apartheidsera is die Ned Geref Kerk dikwels afgemaak as niks anders as "die Nasionale Party in gebed" nie. Aan die ander uiterste is NG-apologete wat geen kritiek teen die Ned Geref sending as legitiem wil aanvaar nie, en die blote omvang van Ned Geref sending in Suid- en Sentraal-Afrika aanvoer as bewys dat alles wel was. Na my mening is selfs hierdie kort verkenning genoeg om aan te dui dat ' $n$ meer ambivalente evaluering waarskynlik gepas is. Opregte menslike sendingentoesiasme (altyd en orals ' $n$ mengsel van "suiwer" en "onsuiwer" motiewe - vgl my voetnoot bo) het in die spesifieke politiek-ekonomiese omstandighede van die periode onder bespreking hopeloos verstrengel geraak met pogings om 'n onregverdige rassistiese bestel te institusionaliseer (vgl Saayman 2001:484). Dit maak nie veel sin om vandag die geskiedenis te beskryf ten einde beskuldigende vingers heen-en-weer te kan wys nie. Dit maak egter wel sin om die geskiedenis te beskryf in ' $n$ poging om die foute nie weer te herhaal nie en sodoende beter medewerkers aan die missio Dei te wees in 'n nuwe politiek-ekonomiese bestel. Om hierdie rede is sosiale sendinggeskied- 
skrywing na my mening ' $\mathrm{n}$ nuwe horison wat vir ons wink in die sendingwetenskap.

\section{Literatuurverwysings}

Bosch D J 1985. "The fragmentation of Afrikanerdom and the Afrikaner churches", in: Villa-Vicencio C \& De Gruchy J (eds). Resistance and hope. South African essays in honour of Beyers Naudé. Kaapstad: David Philip, 57-69.

-, 1991. Transforming mission. Paradigm shifts in theology of mission. Maryknoll: Orbis.

Brown J \& Van Keuren D K (eds) 1991. The estate of social knowledge. Baltimore: Johns Hopkins Univ Press.

Comaroff, J \& J 1991. Of revelation and revolution. Christianity, colonialism and consciousness in South Africa. Volume 1. Chicago: University of Chicago Press.

Crafford D 1982. Aan God die dank Deel 1. Geskiedenis van die sending van die Ned Geref Kerk binne die Republiek van Suid-Afrika en enkele aangrensende buurstate. Pretoria: Ned Geref Kerkboekhandel.

Cronjé J M 1981. Aan God die dank Deel 2. Geskiedenis van die sending van die Ned Geref Kerk buite die Republiek van Suid-Afrika. Pretoria: Ned Geref Kerkboekhandel.

Deist F E 1990. Notes on the context and hermeneutic of Afrikaner civil religion, in: Kritzinger J N J \& Saayman W (eds). Mission in creative tension. A dialogue with David Bosch. Pretoria: SAMS, 124-139.

Du Preez A B 1960. "Die afsonderlike ontwikkeling van Bantoegebiede en die eis wat dit aan ons sendingwerk stel". Ned Geref Teologiese Tydskrif, Maart 1960, I:2, 46-52.

Durand J 1985. "Afrikaner piety and dissent", in: Villa-Vicencio C \& De Gruchy J (eds). Resistance and hope. South African essays in honour of Beyers Naudé. Kaapstad: David Philip, 46-57.

Elphick R 1987. Mission Christianity and interwar liberalism, in: Butler J et al 1987. Democratic liberalism in South Africa: its history and prospect. Kaapstad: David Philip, 64-80.

-, 1992. Religion in South African history: a study in denial. Referaat gelewer by die vyf en dertigste Algemene Jaarvergadering van die African Studies Association, Seattle, VSA.

Flinn M W \& Smout T C (eds) 1974. Essays in social history. Oxford: Clarendon Press.

Gerdener G B A 1958. Recent developments in the South African mission field. Kaapstad: Ned Geref Kerk Uitgewers.

Grundlingh A 1987. Sosiale geskiedenis en die dilemma in Afrikanergeskiedskrywing. SA Historiese Joernaal 19, 31-50.

Hobsbawm E J 1974. From social history to the history of society, in: Flinn M W \& Smout T C (eds) 1974. Essays in social history. Oxford: Clarendon Press, 1-22.

Hoekendijk J C 1948. Kerk en volk in de Duitse Zendingswetenschap. Amsterdam: Kampert \& Helm. 
Krige W A 1954. Die probleem van eiesoortige kerkvorming by Christian Keysser. Franeker: Wever.

Louw A A 1965. Andrew Louw van Morgenster. Pretoria: Ned Geref Kerkuitgewers.

Mariz C L 1994. Coping with poverty: Pentecostals and Christian Base Communities in Brazil. Philadelphia: Temple Univ Press.

O'Meara D 1983. Volkskapitalisme. Class, capital and ideology in the development of Afrikaner nationalism 1934-1948. Johannesburg: Ravan Press.

Truter P J 1995. Die verhouding tussen staatsbeleid en sendingbeleid in die Tomlinsonverslag (1954). Ongepubliseerde M Th-verhandeling, Unisa: Pretoria.

Saayman W 1993. "Christian Keysser revisited", in: Balia D (ed). Signs of the times. Perspectives in theology and mission from South Africa. Lewiston: Mellon Press, 108-118.

-, 1996. “Those pietistic missionaries: a time to reconsider?”, Skrif en Kerk 17(1), 202214.

-, 2001. "Racism and mission enthusiasm: some facets of DRC mission in the aftermath of the Tomlinson Report". Missionalia 29:3, November 2001, 476-485.

Smith N J 2002. "From missio Dei to missio hominum: Christian mission and missiology en route", in: Karecki M (ed). The making of an African person: essays in honour of Willem A Saayman. Pretoria: SAMS, 4-21.

Tomlinsonverslag 1954. Samevatting van die Verslag vir die Sosio-ekonomiese Ontwikkeling van die Bantoegebiede binne die Unie van Suid-Afrika. Pretoria: Staatsdrukker.

Watt C P 2001. Struggle for the centre. South African Pentecostal missiology in context. Unpublished D Th-thesis, Unisa: Pretoria. 